\title{
Obtaining and application of composite materials based on polymer-polymer complexes and phosphogypse
}

\author{
Kamaridin KOMILOV 1 \\ Aypara KURBANOVA ${ }^{2}$ \\ Gafurjan MUKHAMEDOV 3 \\ Jumaqul ALLAYEV 4
}

Chirchik State Pedagogical Institute of Tashkent Region

\begin{tabular}{l} 
ARTICLE INFO \\
\hline Article history: \\
Received March 2021 \\
Received in revised form \\
20 March 2021 \\
Accepted 15 April 2021 \\
Available online \\
20 May 2021
\end{tabular}

Keywords:

phosphogypsum,

chemical ameliorant,

chemical reclamation,

salinization,

gypsum,

calcium dihydrate,

interpolymer complex,

composite material.

\begin{abstract}
The possibility of using bulk waste of the chemical industry phosphogypsum as a useful resource is considered. The results of scientific research and practical experience convincingly proved the technical feasibility and feasibility of using phosphogypsum in the national economy instead of traditional types of natural raw materials. A brief description of phosphogypsum, promising areas for its processing, and some statistics are presented.

The article is about the use of chemical ameliorant based on phosphogypsum for effective feeding in various soil and climatic zones for cereals, vegetables, industrial and other crops, to increase the yield of cotton and the technological quality of its fiber. That the use of phosphogypsum as a chemical ameliorant improves the chemical, physical and water-physical properties of saline soils.
\end{abstract}

2181-1415/C) 2021 in Science LLC.

This is an open access article under the Attribution 4.0 International (CC BY 4.0) license (https://creativecommons.org/licenses/by/4.0/deed.ru)

\footnotetext{
1 Ph.D., Chirchik State Pedagogical Institute of Tashkent Region, Chirchik, Uzbekistan.

E-mail: dos650922@gmail.com.

2 Ph.D., Chirchik State Pedagogical Institute of Tashkent Region, Chirchik, Uzbekistan.

${ }^{3}$ Doctor, Professor, Rector of the Chirchik State Pedagogical Institute of Tashkent Region, Chirchik, Uzbekistan.

${ }^{4}$ Ph.D., Chirchik State Pedagogical Institute of Tashkent Region, Chirchik, Uzbekistan.
} 


\section{Polimer-polimer komplekslar va fosfogips asosida kompozit materiallar olish va qo'llanilishi}

\author{
Kalit so'zlar: \\ fosfogips, \\ kimyoviy meliorant, \\ kimyoviy melioratsiya, \\ sho'rlanish, \\ gips, \\ kaltsiy dihidrat, \\ interpolimer kompleksi, \\ kompozitsion material.
}

\begin{abstract}
ANNOTATSIYA
Maqolada kimyo sanoatining katta miqdordagi chiqindilari fosfogipsdan foydali manba sifatida foydalanish imkoniyati ko'rib chiqilgan. Ilmiy izlanishlar va amaliy tajriba natijalari tabiiy xom ashyoning an'anaviy turlari o'rniga xalq xo'jaligida fosfogipsdan foydalanishning texnik maqsadga muvofiqligi va maqsadga muvofiqligini ishonchli isbotladi. Fosfogipsin qisqacha tavsifi, uni qayta ishlashning istiqbolli yo'nalishlari va ba'zi statistik ma'lumotlar keltirilgan.

Maqola g'alla, sabzavot, sanoat va boshqa ekinlarning turli tuproq-iqlim zonalarida samarali oziqlantirish, paxta hosildorligini va uning tolasining texnologik sifatini oshirish uchun fosfogips asosida kimyoviy meliorantdan foydalanishga bag'ishlangan. Fosfogipsdan kimyoviy meliorant sifatida foydalanish sho'rlangan tuproqlarning kimyoviy, fizik va suvfizik xususiyatlarini yaxshilaydi.
\end{abstract}

\section{Получение и применение композитных материалов на основе полимер-полимер комплексов и фосфогипса}

\footnotetext{
Ключевые слова:

фосфогипс,

химический мелиорант, химическая мелиорация, засоление,

гипс,

дигидрат кальция, интерполимерный комплекс, композиционный материал.
}

\section{АННОТАЦИЯ}

Рассмотрена возможность использования сыпучих отходов химической промышленности - фосфогипса в качестве полезного ресурса. Результаты научных исследований и практический опыт убедительно доказали техническую целесообразность и целесообразность использования фосфогипса в народном хозяйстве вместо традиционных видов природного сырья. Приведено краткое описание фосфогипса, перспективные направления его переработки и некоторые статистические данные.

Статья посвящена применению химического мелиоранта на основе фосфогипса для эффективной подкормки в различных почвенно-климатических зонах зерновых, овощных, технических и других культур, повышения урожайности хлопка и технологического качества его волокна. Использование фосфогипса в качестве химического мелиоранта улучшает химические, физические и водно-физические свойства засоленных почв.

\section{INTRODUCTION}

The rapid pace of development of industry, energy, metallurgy, metalworking, chemical, petrochemical and other industries, as well as areas of engineering, construction and household activities entail the inevitable generation and accumulation of industrial waste on a global scale. And one of the main types of waste is waste from the chemical industry. 
So, in the production of mineral fertilizers, various types of waste are generated, among which phosphogypsum is a waste of the production of phosphate fertilizers [2]. It should be noted that at present, a significant layer of problems of a geoecological nature is generally observed, associated primarily with extensive forms of environmental management, environmental degradation for various reasons [3;4], including the irrational management of many sectors of nature management [5].

Currently, there are more than 60 million tons of phosphogypsum in the dumps of Ammofos-Maxam OJSC and its amount continues to increase annually (in terms of calcium dihydrate). The monitoring studies of the phosphogypsum dump located on the territory of the Almalyk Chemical Plant of Mineral Fertilizers of Ammofos-Maxam OJSC showed that stagnant phosphogypsum has the same chemical and phase composition. The chemical composition of phosphogypsum mainly contains oxides of calcium, sulfur and silicon with an admixture of oxides of iron, aluminum, magnesium, phosphorus, sodium and others. As can be seen from the table, the mass fraction of the main substance (CaSO4 $\cdot 2 \mathrm{H} 2 \mathrm{O})$ in terms of dry dihydrate is $97 \%$, the mass fraction of hygroscopic moisture is $16.4 \%$, the content of water-soluble fluoride compounds in terms of fluorine is $0.12 \%$. Impurities of toxic compounds of cadmium, arsenic,

\section{Chemical analysis resultssamples of phosphogypsum of Ammophos-Maxam 0JSC}

\begin{tabular}{|c|c|c|}
\hline \multirow{2}{*}{ The name of indicators } & \multicolumn{2}{|c|}{ Phosphogypsum (stale), dump of Ammofos OJSC } \\
\hline & density g / cm3 - 2.3 & density g / cm3 - 2.4 \\
\hline 1. P205total & 2.00 & 1.39 \\
\hline 2. SO3 & 44.33 & 44.95 \\
\hline 3. $\mathrm{CaO}$ & 29.81 & 31.33 \\
\hline 4. $\mathrm{Fe} 2 \mathrm{O} 3$ & 0.29 & 0.64 \\
\hline 5. Ftotal & 0.42 & 0.39 \\
\hline 6. $\mathrm{SiO} 2$ & 13.75 & 12.44 \\
\hline 7. Al203, & 0.31 & 0.58 \\
\hline 8. Fe203 & 0.29 & 0.64 \\
\hline 9. $\mathrm{MgO}$ & footprints & 0.5 \\
\hline Insoluble residue & 9.09 & 7.78 \\
\hline
\end{tabular}

According to technical characteristics stale phosphogypsum, placed on the dump of the AmmofosMaxam mineral fertilizer plant, meets the requirements of TU 113-08-418-94 "Phosphogypsum for agriculture" grade No. 2 and therefore can be used for chemical land reclamation.

For specimens of stagnant phosphogypsum (wastes of Ammofos-Maxam OJSC) the specific effective activity of natural radionuclides was determined, on the basis of which the sanitary and epidemiological conclusion was given that phosphogypsum samples 
correspond to SP No. 202 of 03.02.2012. "Sanitary and epidemiological requirements for ensuring radiation safety" and phosphogypsum can be used in economic activities without restrictions. For phosphogypsum samples, toxicological parameters were determined, which showed that the toxicity value of the aqueous phosphogypsum filtrate in the experiment on laboratory animals (white mice) corresponds to the 4th hazard class. The total toxicity index of the phosphogypsum sample is 7.53 units, which according to GOST 30774-2001 classifies this waste as hazard class 5 (non-hazardous).

The total area of solonetz Soils in the Republic of Uzbekistan make up more than 2 million hectares, of which about $50 \%$ of the irrigated lands of Khorezm and the Republic of Karakalpakistan were subjected to salinization, salinization, and loss of nutrient reserves. For this reason, crop yields on these lands decreased by almost 2 times.

To increase crop yields on solonetzic and saline soils, it is necessary to increase calcium reserves in them by adding calcium-containing chemical ameliorants (gypsum, phosphogypsum). Under the conditions of the abovementioned viloyats, the most effective chemical reclamant is phosphogypsum, obtained as an industrial waste of phosphorus production. The Ammophos-Maxam plant in Almalyk has accumulated a huge amount (over 60 million tons) of phosphogypsum, which consists mainly of calcium sulfate dihydrate (CaSO4 - 2H20), phosphogypsum also contains phosphates $(1.3-2.9 \%)[20,21]$.

The main leaders in the production of phosphate raw materials and products made from it are the United States (43.97 million tons), China (29.0 million tons), Morocco (23.59 million tons) - data for 2000 and Russia (10.29 million tons) - data for 2006. It should be noted that our country traditionally occupies one of the leading places in the world market of phosphate raw materials [1]. In Russia, the largest holdings in the mineral fertilizer industry are Fosagro, Euro Chem and Acron [7].

\section{METHODS AND RESULTS}

Extraction phosphoric (orthophosphoric) acid (EPA) is the basic product in the production of most of the elemental phosphorus, concentrated simple and complex fertilizers, and feed phosphates. In our country, Khibiny Apatite concentrate is used for its production. In industry, there are two methods for producing phosphoric acid: thermal and extraction. The thermal method of producing phosphoric acid consists in the hightemperature reduction of phosphates and sublimation of elemental phosphorus in electric furnaces, which is then oxidized to phosphoric anhydride, which forms phosphoric (thermal) acid during hydration. The main method for producing EPA is the displacement of phosphoric acid from raw materials by strong acids. As the displacing acid can be used: sulfuric, nitric, phosphoric, as well as mixtures thereof. Over 70\% of natural phosphate raw materials worldwide are processed using sulfuric acid, hence the name of the production method - sulfuric acid (extraction). Thermal acid is cleaner than extractive, even when using low quality raw materials, which is its advantage. However, at present, there is a decrease in the production of thermal acid, since the process of its production seems to be very energy intensive. In this regard, it is more expensive. However, at present, there is a decrease in the production of thermal acid, since the process of its production seems to be very energy intensive. In this regard, it is more expensive. However, at present, there is a decrease in the production of thermal acid, since the process of its production seems to be very energy intensive. In this regard, it is more expensive.

The decomposition of apatite concentrate with sulfuric acid is described by the following equation (phosphoric acid dissolution of fluorapatite): 


\section{$\mathrm{Ca}_{5}\left(\mathrm{PO}_{4}\right)_{3} \mathrm{~F}+5 \mathrm{H}_{2} \mathrm{SO}_{4}+n \mathrm{H}_{3} \mathrm{PO}_{4}+\mathrm{mH}_{2} \mathrm{O} \rightarrow(\mathrm{n}+3) \mathrm{H}_{3} \mathrm{PO}_{4}+5 \mathrm{CaSO}_{4} \cdot \mathrm{mH}_{2} \mathrm{O}+\mathrm{HF}$}

Phosphoric acid is extracted during the reaction, and calcium sulfate and fluorinated gases are also formed.

Depending on the temperature and concentration conditions of the process, calcium sulfate crystalline hydrates (solid phase) may precipitate in the form of dihydrate, hemihydrate or anhydrite. These forms of the existence of calcium sulfate when changing the mode of conducting the process can go from one to another. Accordingly, dihydrate, hemihydrate and anhydrite methods for the production of phosphoric acid are isolated.

Calcium sulfate dihydrate or hemihydrate formed as a by-product due to the content of P205 impurities in them (undecomposed phosphate, undisturbed phosphoric acid, cocrystallized P205) is called phosphogypsum or phospho-hemihydrate, respectively. But when considering the problems of transportation, storage and use, both products are usually called phosphogypsum [6; 8; nine].

Phosphogypsum is a white to gray color finely dispersed, close to monomineral powder, having high humidity when leaving the chemical plant, according to various sources, from 25 to $45 \%$. Its chemical composition may depend on the type of phosphate feedstock, production method and method of storage [8; fifteen].

Removing a by-product involves choosing the most reliable and economical way to transport and store it, taking into account the specific conditions of each enterprise. Currently, two main directions of phosphogypsum utilization are practiced in the world: discharge into water bodies (rivers, seas) and laying on land. The first method is practiced only by some states: Morocco, Tunisia, the countries of South Africa and Mexico, which is approximately 5\% [10]. Ground-based storage of waste requires special engineering structures for storage and is carried out in the so-called "dry" dumps or in hydraulic dumps (reclaimed or bulk gypsum storage tanks) $[11,12]$. The drive has one or another name depending on the method of transportation:

- "Dry" (semi-dry selection) - with the movement of wet waste without neutralization by road. In Russia, this method is practiced, for example, by Phosphorit Production Association (Kingisepp, Leningrad Region) and Apatit BF JSC (Balakovo, Saratov Region).

- "Wet" (hydrotransport) - the waste is fed to the dump by hydrotransport via a slurry pipeline after neutralizing acids in the liquid phase with lime and repulping. Examples are enterprises: OJSC Metakhim (Volkhov, Leningrad Region), Production Association Ammofos (Cherepovets) and EuroChem-BMU LLC (Belorechensk, Krasnodar Territory).

In the formation of this kind of mining structures are guided, first of all, by economic and environmental principles, the meaning of which is to ensure maximum technical and economic efficiency with minimal disturbance of the natural environment. One way or another, the ecological balance is disturbed, which is associated with a change in the natural landscape, pollution of the soil cover, deterioration of the atmospheric air, changes in the condition and properties of rocks that form the foundations of dumps, hydrological and hydrogeological regimes, etc. $[13,14]$. 
The problem of using phosphogypsum as a secondary raw material for the production of liquid products has been relevant since the 60s. XX century. The results of numerous studies and practices convincingly proved the technical feasibility and feasibility of using phosphogypsum in the national economy instead of traditional types of natural raw materials [15]. This is due to the content in gypsum from 80 to $98 \%$ gypsum, which allows it to be attributed to gypsum raw materials. Here it should be noted the most promising areas of using phosphogypsum as a valuable large-tonnage secondary resource:

- in agriculture for chemical reclamation of acid and solonetzic soils and composting with organic fertilizers;

- in the cement industry, as a mineralizer - additives to the raw material mixture and as a regulator of setting speed - instead of natural gypsum;

- for the production of gypsum binders and products, filler in the manufacture of plastics, glass;

- in the construction of roads, the construction of buildings and structures;

- at arrangement of sea and coastal zones;

- for the production of sulfuric acid, etc.

These examples on the involvement of phosphogypsum are mostly positive, but quantitatively this is only $15 \%$ worldwide. The remaining $85 \%$ are sent to dumps. This is due to the fact that phosphogypsum is contaminated with various impurities (sulfuric acid, potassium and sodium salts, fluorides and silicofluorides, silicon oxide, rare earth elements, radioactive substances, etc.), which do not allow replacing them with natural gypsum. In turn, the need for the use of complex and expensive equipment for the preparation of phosphogypsum as a recyclable material, as well as existing methods, processes and technologies, require large amounts of energy and heat in comparison with the processing of natural gypsum raw materials. Hence the high cost of phosphogypsum. An exception are countries that do not have deposits of natural gypsum, for example, Japan, which completely processes it. Another factor limiting the use of phosphogypsum is radioactivity. It is known that radioactive elements migrate in a certain amount during the processing of phosphate raw materials [14]. The most radioactive are phosphogypsum from Sweden, Spain and Morocco, which also complicates the involvement of waste in production. Without additional processing, phosphogypsum is suitable for the construction of pavement foundations, but only in cases where they are not subject to increased requirements for frost resistance.

The quality of irrigation of crops largely depends on the uniformity of wetting of the irrigated area. A number of studies have been devoted to this $[17,18]$. It should be noted that there are still no reliable irrigation equipment and technologies that would ensure a more uniform distribution of irrigation water in the field. It seems very advisable to achieve a uniform distribution of water along the length of the irrigation furrow, supplying less irrigation water.

In connection with the above, laboratory and field studies were carried out using composite materials (CM) as devices for drip irrigation. Irrigation was carried out on trays made of KM with dispersed fillers having the appearance of a furrow and installed on the ridges of the furrow next to cotton. Trays from the obtained interpolymer material with a filler were made using special molds (Fig. 1). 


\section{RESULTS AND DISCUSSION}

The problem was solved in such a way that several trays with certain pore sizes were placed next to each other along the furrow, at a distance of the length of run-off of irrigation water. Water saving is achieved by eliminating the discharge of water, as well as ensuring uniform soil moisture along the entire length of the furrow.

The irrigation tray is used as follows: water from the dispensers (Fig. 2.) (1), through a filter (2) made of polymer material, enters the trays and through it enters the soil. Water consumption is governed by the size of micropores (3) obtained by the selection of percentages of components of the polymer material. The filter (2), which is made of the same material, eliminates clogging of the trays. Irrigation water is supplied to the soil through the pores of the tray in the form of droplets. Pore sizes can be adjusted by changing the composition of the CM. The width of the trays is $10 \mathrm{~cm}$, the depth is $12 \mathrm{~cm}$, and the length is $100 \mathrm{~cm}$. By connecting them in series, the required length can be achieved.

The distribution of irrigation norms by soil layers was determined according to the variants of small-plot experiments in triplicate. Watering was carried out without discharge. The soils of the site are automorphic, medium loam in terms of mechanical composition. The optimal rate of absorption of water into the soil was $0.016-0.017 \mathrm{~m} / \mathrm{h}$. The level of moistened soil layers at the beginning and end of the furrow was 50 and 45 $\mathrm{cm}$ for the first, $62-51 \mathrm{~cm}$ - second and 81-69 cm - third watering, respectively.

The balance equation of irrigation norms has been compiled:

$m b r=m 1+m 2+m 3 ;$

where mbr - irrigation rate supplied to the site, $\mathrm{m} 3$ / ha;

$\mathrm{m} 1$ - estimated irrigation rate, $\mathrm{m} 3$ / ha;

$\mathrm{m} 2$ - water loss due to evaporation, $\mathrm{m} 3$ / ha;

$\mathrm{m} 3$ - soil moisture below the calculated layer, $\mathrm{m} 3$ / ha

Irrigation rates by layers were determined by the size of soil moisture before and after irrigation after 3, 5, 7, 10, 15 days and were calculated by the formula:

$\mathrm{m}=100 \mathrm{Hd}(\mathrm{Pnv}-\mathrm{Pf})$,

where $\mathrm{N}$ is the calculated soil layer, $\mathrm{m}$;

$\mathrm{d}$ - soil density, $\mathrm{t} / \mathrm{m} 3$;

Rnv, Rf - humidity at the lowest moisture capacity and actual before irrigation, $\%$ of the mass of dry soil.

When irrigating with water flow rates of 0.4-0.6 l / s with irrigation rates of gross $600-650 \mathrm{~m} 3$ / ha, when the norm below the calculated layer was $20-35 \mathrm{~m} 3$ / ha (3.3-5\%) and water loss for evaporation - 30-33 $\mathrm{m} 3$ / ha (5\%), the calculated irrigation rate will be $550-581 \mathrm{~m} 3$ / ha. The use of relatively lower irrigation rates of up to $600 \mathrm{~m} 3$ / ha and compliance with irrigation regimes ensured an increase in yield by $3.4 \mathrm{c} / \mathrm{ha}$, in contrast to the control plot [19]. 


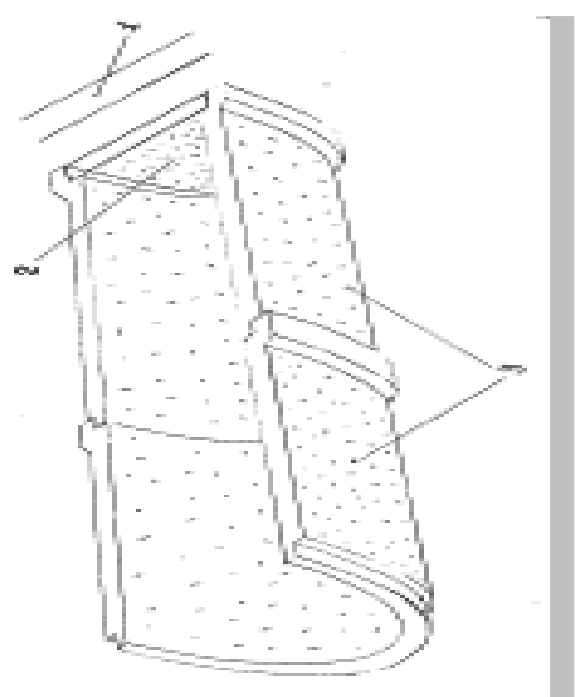

Fig. 1. General view of the irrigation tray, obtained from a polymer material based on IPKMFS with phosphogypsum and sand.

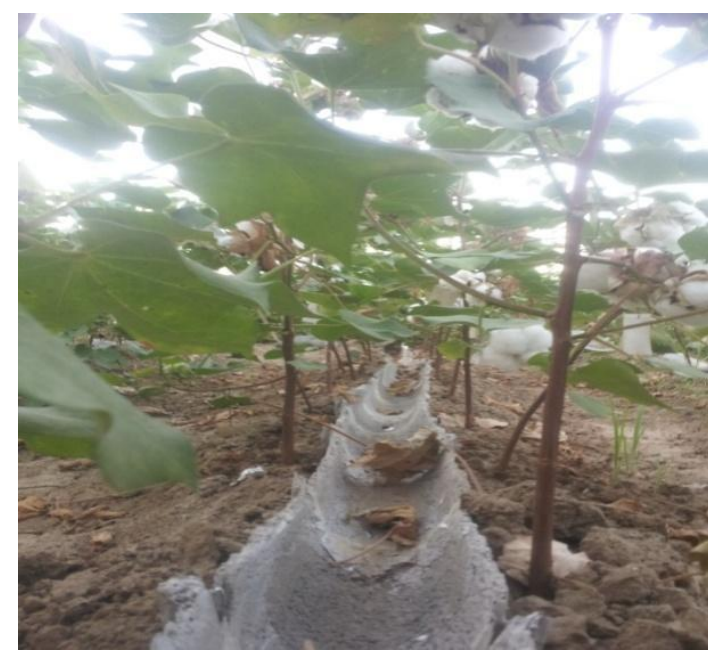

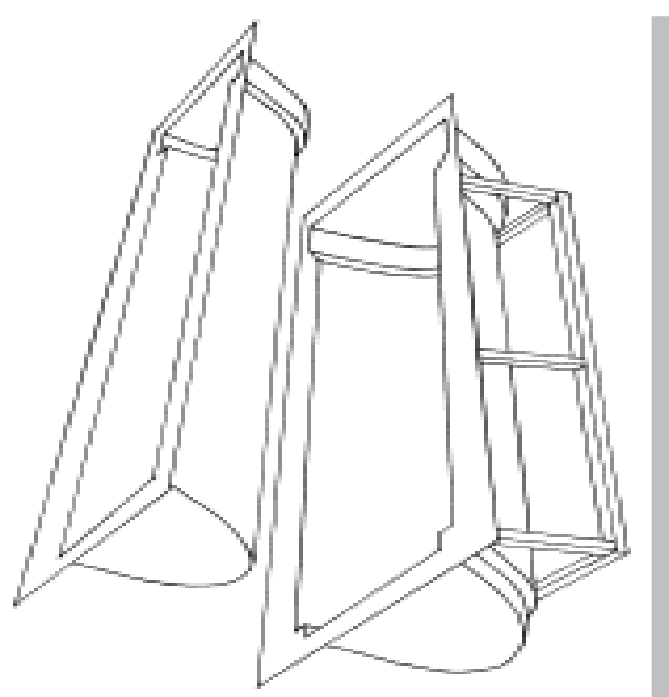

Fig. 2. Form for the manufacture of interpolymer material based on IPK-MFS with phosphogypsum and sand.

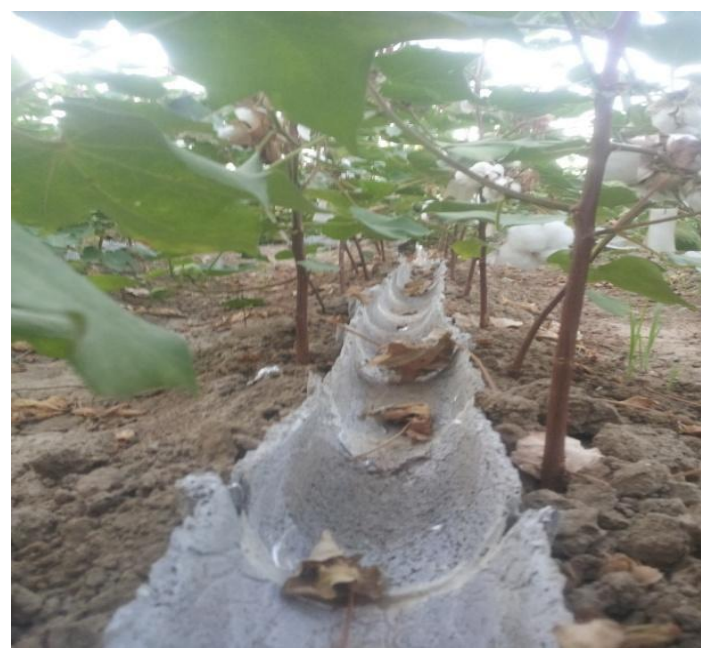

Fig. 3. Practical application of the obtained porous material from phosphogypsum to reduce the irrigation rate.

\section{CONCLUSION}

According to forecasts, by 2040 the amount of waste can double. The question of bringing phosphogypsum to such a state that it is possible to use it whole and it is costeffective, or to assimilate waste in the natural environment without compromising its natural state, is as relevant as ever. Thus, the current problems of nature management and waste generation are interrelated, which requires a phased and at the same time comprehensive solution.

It was found that the developed interpolymer materials with excess sodium carboxymethyl cellulose salt can be used as highly swelling hydrogels and an anti-filter screen, and with excess urea-formaldehyde resin and dispersed fillers to save irrigation water (uniform distribution of water along the length of the irrigation furrow). The fact of their role in saving water and cotton productivity is confirmed. 


\section{REFERENCES:}

1. Angelov A.I., Levin B.V. Chernenko Yu.D. Phosphate raw materials // Reference. M.: Nedra-Business Center LLC. 2000. - P. 120.

2. Halperin A.M., Förster V., Chef H.-J. Man-made arrays and the protection of natural resources: Textbook for universities: 2 volumes. - M.: Publishing house of Moscow State University, 2006. T. 1: Bulk and alluvial massifs. - P. 391.

3. Larionov M.V., Smirnova E.B., Burdin M.V. Environmental degradation in the zone of influence of technogenic and agricultural objects // Bulletin of the Samara Scientific Center of the Russian Academy of Sciences. 2011. V. 13. No. 1-6. - PP. 1347-1349.

4. Larionov N.V., Larionov M.V. Heavy metals as a factor of technogenic impact on soils of urboecosystems of the Saratov region // Bulletin of KrasGAU. 2009. No. 11. PP. 22-26.

5. Larionov N.V., Larionov M.V. Ecological features of nature management in the Middle and Lower Volga // Natural and mathematical sciences in the modern world. 2015. No. 28. - PP. 58-64.

6. Meshcheryakov Yu.G., Fedorov S.V. Industrial processing of phosphogypsum. St. Petersburg: Stroyizdat St. Petersburg, 2007. - P. 104.

7. Phosphate and raw material base of Russia: new technologies and development prospects / Nepryakhin A.E., Senators P.P., Karpova M.I. // Mining equipment. 2009. No. 4. P. 136-144.

8. Phosphogypsum and its use / V.V. Ivanitsky, P.V. Klassen, A.A. Novikov et al. - M.: Chemistry, 1990. - P. 224.

9. Best Available Techniques for Pollution Prevention and Control in the European Fertilizer Industry, Booklet No. 4 of 8: Production of phosphoric acid, European Fertilizer Manufacturers' Association, EFMA B-1160, Brussels, Belgium.

10. Fuleihan, Nadim F., Phosphogypsum disposal - The pros \& cons of wet versus dry stacking // Florida, 2011. - P. 11.

11. Gennari RF, Garcia I., Medina NH, Silveira MAG Phosphogypsum analysis: Total content and extractable element concentrations, International Nuclear Atlantic Conference. 2011, Brazil.

12. Hilton, Julian, Phosphogypsum (PG): Uses and Current Handling Practices Worldwide, Proceedings of the 25th Annual Lakeland Regional Phosphate Conference. October 13-14, 2010, London UK.

13. Larionov MV Scheme technogenic stress of natural and artificial landscapes of the Saratov and Volgograd regions // Theoretical and applied questions of science and education: at 4 pm Part 15. Tambov, 2015. - PP. 8-9.

14. Pe'rez-Lo'pez R., A' lvarez-Valero AM, Nieto JM Changes in mobility of toxic elements during the production of phosphoric acid in the fertilizer industry of Huelva (SW Spain) and environmental impact of phosphogypsum wastes / J. of Hazardous Materials 148 (2007) - PP.745-750.

15. Tayibi H., Choura M., López FA, Alguacil JA, López-Delgado A. (2009). Environmental impact and management of phosphogypsum (Review). J. Environ. Manage. 90, 2377-2386.

16. Korobanova T.N. Russian and foreign experience in the utilization of phosphogypsum // Science yesterday, today, tomorrow: Sat. Art. by mater. XL Int. scientific-practical conf. No. 11 (33). - Novosibirsk: SibAK, 2016. - PP. 63-71. 
17. Laktaev N.T. Theoretical substantiation of the technique of irrigation of crops on furrows: Proceedings of the Agricultural Academy. "The technique of irrigation of crops" M.: 1972. - P. 61.

18. Kambarov B.F. Improving the technique of furrow irrigation, taking into account the protection of soils from irrigation erosion in conditions of large slopes and complex reliefs: Abstract. diss. ... cand. tech. sciences. - Tashkent: 1972. - P.15.

19. Kamilov K.U. Non-stoichiometric interpolymer complexes based on urea formaldehyde resin and dispersed fillers: Diss. ... cand. tech. sciences. - Tashkent: 2005.

20. Recommendations for the reclamation of solonetzic lands. - M.: Kolos, 2003. - P. 46.

21. Ivanitsky V.V., Klassen P.V., Novikov A.A. Phosphogypsum and its use. - M.: Chemistry, 2000. - P. 224. 